\title{
Pengaruh Berat Bibit Dan Pupuk NPK Terhadap Pertumbuhan Dan Hasil Tanaman Jahe Pada Tanah Gambut
}

\section{(The Influence of the Weight of NPK Seeds and Fertilizers on the Growth and Yield of Ginger Plants on Peat Soil)}

\author{
Samiri $^{1 *}$, Radian$^{2}$, dan Sutarman Gafur ${ }^{2}$ \\ ${ }^{1}$ Prodi Magister Agroteknologi, Fakultas Pertanian, Universitas Tanjungpura \\ ${ }^{2}$ Jurusan Budidaya Pertanian, Fakultas Pertanian, Universitas Tanjungpura \\ Jl. Prof. Dr. H. Hadari Nawawi Pontianak 78124, Indonesia \\ *Email Korespondensi: samiritarmizi@gmail.com
}

Diterima 10 Juli 2019/ Disetujui 03 September 2019

\begin{abstract}
Ginger is one of the commodities that has been being used since thousands years ago, and used as the ingredient and spices which is put in trade world wide. This research aims to investigate the weight of the rhizome and NPK fertilizer toward the growth and the crops of the ginger in peat soil. This research was conducted in the Vocational High School of Mempawah Timur, Antibar Village, Mempawah Regency. This research took 6 months, starting from April to December 2018. This research applied Completely Randomizet Design. The first factorial is the weight of rhizoma $(B)$ and NPK fertilizer $(P)$. This design is done by factorial (4X5) with three replications, then the number of the beds were $4 \times 5 \times 3=60$ beds, each bed consists of 25 plants. There happened an interaction between rhizome and NPK fertilizer towards the dependent variable, plant height at 150 HST (the day after plantation) and 180 HST, the number of bud at 90 HST, 120 HST, 150 HST and the rhizome dry weight at 60 HST.
\end{abstract}

Keywords: seed weight, npk fertilizer, ginger

\section{ABSTRAK}

Jahe merupakan salah satu komoditi yang sejak ribuan tahun yang lalu digunakan untuk ramuan dan rempah-rempahan yang diperdagangkan secara luas didunia. Penelitian ini bertujuan untuk mengetahui pengaruh berat bibit dan pupuk NPK terhadap pertumbuhan dan hasil tanaman jahe pada tanah gambut. Dilaksanakan di SMK N 1 Mempawah Timur, desa Antibar, Kecamatan Mempawah Timur, Kabupaten Mempawah. Waktu pelaksanaan penelitian berlangsung selama 6 Bulan, mulai bulan April sampai dengan Desember 2018. Penelitian ini menggunakan Rancangan Acak Lengkap (RAL) faktorial. Faktor pertama adalah berat bibit $(B)$ Faktor kedua pupuk NPK $(P)$. Interaksi terjadi antara berat bibit dan perlakuan pupuk NPK pada variabel pengamatan tinggi tanaman pada umur 150 HST dan 180 HST, jumlah tunas pada umur 90 HST, 120 HST, 150 HST dan berat kering rimpang pada umur $60 \mathrm{HST}$.

Kata Kunci: berat bibit, pupuk npk, jahe

\section{PENDAHULUAN}

Jahe (Zingiber officinale Rosc) merupakan salah satu komoditas yang sudah sejak ribuan tahun yang lalu digunakan sebagai bagian dari ramuan rempah-rempah yang diperdagangkan secara luas di dunia. Masyarakat Indonesia umumnya telah mengenal dan memanfaatkan tanaman ini dalam kehidupan sehari-hari untuk berbagai kepentingan seperti: campuran bahan makanan, minuman, kosmetik, parfum dan lain-lain mulai dari tingkat tradisional di pedesaan sampai tingkat modern di perkotaan.

Dalam beberapa tahun terakhir ini, pertanian jahe cendrung terus meningkat, jahe dimempawah memiliki peluang yang cukup besar untuk dikembangkan, karena dari segi rasa lebih pedas, aroma yang khas dan serat lebih halus dibanding jahe yang dari pulau jawa, sehingga banyak permintaan pasar baik dari dalam negeri maupun luar negeri terutama Serawak Malaysia, Komoditi jahe layak dijadikan salah satu komoditi unggulan kalimantan barat.

Pemanfaatan tanah gambut sebagai lahan budidaya pertanian dihadapkan pada berbagai kendala yaitu sifat fisik, kimia dan biologi yang kurang baik. Tanah gambut merupakan tanah organik yang mempunyai sifat fisik yang gembur, tetapi drainase dan aerase jelek karena jenuh air, sehingga sifat biologi tanah gambut juga menjadi jelek. Perkembangan dan aktivitas mikroorganisme terhambat, proses dekomposisi gambut berjalan sangat lambat. Hal ini berdampak terhadap pada sifat kimia yang jelek seperti ketersediaan hara rendah, kejenuhan basa rendah, kapasitas tukar kation tinggi dan kemasaman tanah tinggi. Kondisi 
tersebut tidak menunjang terciptanya laju dan penyediaan hara yang memadai bagi tanaman terutama hara makro dan mikro seperti N, P, K, Ca, Mg dan Cu (Radjagukguk, 1991). Selain itu kelarutan asam organik seperti asam humat dan asam fenolat juga tinggi. Agar tanah gambut ini dapat menjadi tanah yang baik untuk budidaya tanaman jahe dapat dilakukan pemupukan sebagai sumber hara. Ketersediaan unsur hara bagi tanaman selama pertumbuhan sangat diperlukan, karena ketersediaan unsur hara merupakan syarat utama dalam meningkatkan produksi tanaman.

Selain pupuk NPK juga berpengaruh ukuran berat bibit. Hailemichael dan Tesfave (2008), melaporkan bahwa semakin besar ukuran rimpang, maka akan semakin berpengaruh nyata dalam meningkatkan pertumbuhan tanaman, komponen hasil, dan bobot kering rimpang jahe.

Penelitian ini bertujuan untuk mengetahui pengaruh berat bibit, pupuk NPK dan interaksi antara berat bibit dan pemupukan NPK terhadap pertumbuhan dan hasil tanaman jahe.

\section{BAHAN DAN METODE}

Penelitian ini dilaksanakan di SMK N 1 Mempawah Timur, Desa Antibar Kecamatan Mempawah Timur Kabupaten Mempawah. Waktu pelaksanaan penelitian berlangsung selama 6 Bulan. Mulai dari bulan April sampai Oktober 2018. Bahan Pelitian yang digunakan yaitu Bibit Jahe, Kapur Dolomit, Pupuk NPK, Festisida. Alat yang digunakan yaitu Parang, Cangkul, Handsprayer, Alat tulis, Meteran, Timbangan, Alat dokumentasi.

Penelitian ini dilaksanakan dengan menggunakan RAL. Pola Faktorial terdiri dari 2 faktor perlakuan. Adapun faktor-faktor dimaksud adalah berat bibit (B) dan Pupuk NPK (P). Rancangan ini dilakukan faktorial ( 4 x 5 ) dan tiga ulangan, maka jumlah bedengan 4 × 5 × $3=60$ bedengan, setiap bedengan ada 25 tanaman.

Pelaksanaan penelitian dimulai dari persiapan benih jahe. Benih jahe didapatkan dari rimpang jahe yang yang berumur $9-12$ bulan, dengan empat macam perlakuan berat bibit yaitu 8 g-12 g, 18 g -22 g, 28 g -32 g dan 38 g -42 g. Kemudian benih jahe dianginkan selama satu minggu baru disemai ketanah dengan cara persiapan media persemaian campuran antara tanah gambut, pupuk kandang dan abu dengan perbandingan $2: 1: 1$. Bibit jahe disemai kemudian ditutup plastik dan diberi naungan. Selama dua minggu dan disiram sesauai kebutuhan dengan menggunakan sprayer, dimana penyiraman dilakukan dengan membuka plastik hingga basah, bibit jahe siap tanam setelah umur dua minggu dimana sudah muncul tunas dengan tinggi sekitar $1 \mathrm{~cm}-2 \mathrm{~cm}$.

Pengolahan tanah dengan cara dicangkul dengan kedalaman kurang lebih $20 \mathrm{~cm}$ dengan tujuan untuk mendapatkan kondisi tanah yang gembur atau remah dan membersikan dari tanaman pengganggu. Kemudian baru dibuat bedengan dengan ukuran lebar $150 \mathrm{~cm}$, panjang 150 $\mathrm{cm}$, tinggi bedengan $20 \mathrm{~cm}$ dan jarak antar bedengan $50 \mathrm{~cm}$ kemudian diratakan dengan cangkul.
Kapur yang digunakan kapur dolomit, yang diberikan 2 minggu sebelum tanam dan dicampur merata dengan tanah dengan dosis $1,383 \mathrm{~kg}$ per bedengan.

Pupuk NPK yang digunakan, pupuk NPK mutiara yang diberikan 3 kali, pemberian pertama bersamaan dengan waktu tanam, yang kedua 2 bulan setelah tanam dan ketiga 4 bulan setelah tanam dengan dosis yang telah ditentukan. Naungan dari paranet $75 \%$ dengan tinggi naungan $120 \mathrm{~cm}$.

Sebelum melak ukan penanaman terlebih dahulu membuat lobang tanam dengan kedalaman $3-7 \mathrm{~cm}$ kemudian tanah digemburkan. Bibit jahe ditanam setelah bibit berumur dua minggu atau bibit telah bertunas sebanyak 1 batang dengan tinggi tunas yang seragam $1-2 \mathrm{~cm}$. Bibit dipilih yang mempunyai pertumbuhan serempak dan seragam. Bibit dipindahkan dengan cara memindahkan bibit dari persemaian ke bedengan, dengan jarak tanam 30 x $30 \mathrm{~cm}$, dimana dalam satu lobang tanam jahe ditanam sebanyak satu bibit dengan ukuran yang telah ditentukan.

Penyiraman, penyulaman, penyiangan pembumbunan dan pengendalian hama dan penyakit.

\section{HASIL DAN PEMBAHASAN}

Hasil analisis keragaman pada Tabel 1dan 2 menunjukan bahwa berat bibit dan pemberian pupuk NPK memberikan pengaruh nyata terhadap variabel tinggi tanaman. Berat bibit 38g - 42g dan pupuk NPK 10g/tanaman merupakan berat bibit dan dosis terbaik terhadap variabel pengamatan tinggi tanaman.

Hasil uji BNJ 5\% pada Tabel 1 terhadap parameter tinggi tanaman pada umur 60 HST dengan berat bibit $8 \mathrm{~g}-12$ $\mathrm{g}$ (b1) berbeda tidak nyata dengan tinggi tanaman pada berat bibit $18 \mathrm{~g}-22 \mathrm{~g}$ (b2). Namun berbeda nyata dengan berat berat bibit $28 \mathrm{~g}-32 \mathrm{~g}$ (b3) dan $38 \mathrm{~g}-42 \mathrm{~g}$ (b4). Hasil jumlah rerata berat bibit terendah pada umur $60 \mathrm{HST}$ adalah $8 \mathrm{~g}-12$ $\mathrm{g}$ (b1) yaitu $27,33 \mathrm{~cm}$ dan hasil rerata berat bibit tertinggi pada $38 \mathrm{~g}$ - $42 \mathrm{~g}$ (b4) tanaman yaitu 43,13cm. Sedangkan umur 90 HST dan 120 HST $38 \mathrm{~g}$ - $42 \mathrm{~g}$ (b4) berbeda nyata dengan berat bibit $8 \mathrm{~g}-12 \mathrm{~g}$ (b1), $18 \mathrm{~g}-22 \mathrm{~g}$ (b2) dan $28 \mathrm{~g}-32 \mathrm{~g}$ (b3). Hasil jumlah rerata berat bibit terendah pada umur 90 HST dan 120 HST adalah $8 \mathrm{~g}-12 \mathrm{~g}$ (b1) yaitu 30,86 cm dan 34,8 $\mathrm{cm}$ dan hasil rerata berat bibit tertinggi pada umur 90 HST dan 120 HST adalah $38 \mathrm{~g}-42 \mathrm{~g}$ (b4) tanaman yaitu 51,86 $\mathrm{cm}$ dan $55,8 \mathrm{~cm}$.

Hasil uji BNJ 5\% Pada Tabel 2 menunjukan pada umur $60 \mathrm{HST}$, $90 \mathrm{HST}$ dan $120 \mathrm{HST}$ terhadap parameter tinggi tanaman dengan pemberian dosis pupuk NPK 10 g/tanaman berbeda nyata dibanding dengan tinggi tanaman pada pemberian dosis pupuk NPK $0 \mathrm{~g} /$ tanaman (p0), tetapi berbeda tidak nyata dengan tinggi tanaman dosis pupuk 5g/tanaman (P2) dan 7,5 g/tanaman (P3). Hasil jumlah rerata tinggi tanaman pemberian dosis pupuk terendah pada pemberian pupuk $0 \mathrm{~g} /$ tanaman (P0) yaitu umur $60 \mathrm{HST} 29,83$ $\mathrm{cm}$, umur 90 HST $36,66 \mathrm{~cm}$ dan umur $120 \mathrm{HST} 38,75 \mathrm{~cm}$. Dan hasil rerata tinggi tanaman tertinggi pada pemberian dosis pupuk 10g/tanaman (P4). Yaitu umur $60 \mathrm{HST} 36,33 \mathrm{~cm}$ umur 90 HST $46 \mathrm{~cm}$ dan umur 120 HST $50,91 \mathrm{~cm}$. 
Tabel 1. Uji BNJ $5 \%$ Pengaruh berat bibit terhadap tinggi tanaman

\begin{tabular}{cccc}
\hline \multirow{2}{*}{ Berat Bibit } & \multicolumn{4}{c}{ Tinggi tanaman (Cm) } \\
\cline { 2 - 4 } & 60 HST & 90 HST & 120 HST \\
\hline B4 & $43,13 \mathrm{a}$ & $51,86 \mathrm{a}$ & $55,8 \mathrm{a}$ \\
B3 & $34,06 \mathrm{~b}$ & $44,06 \mathrm{~b}$ & $47,73 \mathrm{~b}$ \\
B1 & $30,93 \mathrm{bc}$ & $38,6 \mathrm{~b}$ & $42,33 \mathrm{c}$ \\
\hline BNJ 5\% & $27,33 \mathrm{c}$ & $30,86 \mathrm{c}$ & $34,8 \mathrm{~d}$ \\
\hline
\end{tabular}

Keterangan : : Angka yang diikuti oleh huruf yang sama berbeda tidak nyata pada uji BNJ 5\%

Tabel 2. Uji BNJ $5 \%$ pengaruh dosis pupuk NPK terhadap tinggi tanaman

\begin{tabular}{cccc}
\hline \multirow{2}{*}{ Dosis NPK } & \multicolumn{3}{c}{ Tinggi tanaman $(\mathbf{C m})$} \\
\cline { 2 - 4 } & 60 HST & 90 HST & 120 HST \\
\hline P4 & $36,33 \mathrm{a}$ & $46 \mathrm{a}$ & $50,91 \mathrm{a}$ \\
P3 & $33,25 \mathrm{ab}$ & $42,41 \mathrm{ab}$ & $47,6 \mathrm{ab}$ \\
P1 & $32,92 \mathrm{ab}$ & $42 \mathrm{ab}$ & $44,58 \mathrm{abc}$ \\
P0 & $36,75 \mathrm{a}$ & $39,66 \mathrm{ab}$ & $43,91 \mathrm{bc}$ \\
\hline BNJ 5\% & $29,83 \mathrm{~b}$ & $36,66 \mathrm{~b}$ & $38,75 \mathrm{c}$ \\
\hline
\end{tabular}

Keterangan : : Angka yang diikuti oleh huruf yang sama berbeda tidak nyata pada uji BNJ 5\%

Tabel 3. Uji BNJ $5 \%$ pengaruh berat bibit dan dosis pupuk NPK terhadap tinggi tanaman 150 HST

\begin{tabular}{ccccccc}
\hline & & P0 & P1 & P2 & P3 & P4 \\
\hline & B1 & $29,67 \mathrm{~h}$ & $40,33 \mathrm{efgh}$ & $35,67 \mathrm{fgh}$ & $34,67 \mathrm{gh}$ & $43,67 \mathrm{defgh}$ \\
& B2 & 43defgh & $47 \mathrm{cdefg}$ & $42,33 \mathrm{defgh}$ & $45 \mathrm{defgh}$ & $44,67 \mathrm{defgh}$ \\
& B3 & 45,67defg & $50,33 \mathrm{bcdef}$ & $49 \mathrm{bcdefg}$ & $57,33 \mathrm{abcd}$ & $57,33 \mathrm{abcd}$ \\
& B4 & 47cdefg & $54,33 \mathrm{abcde}$ & $61,67 \mathrm{abc}$ & $64,33 \mathrm{ab}$ & $68 \mathrm{a}$ \\
\hline \multirow{2}{*}{ BNJ 5\% } & \multicolumn{2}{c}{15,34} & & & & \\
\hline
\end{tabular}

Keterangan : : Angka yang diikuti oleh huruf yang sama berbeda tidak nyata pada uji BNJ 5\%

Tabel 4. Uji BNJ $5 \%$ pengaruh berat bibit dan dosis pupuk NPK terhadap tinggi tanaman 180 HST

\begin{tabular}{ccccccc}
\hline & P0 & P1 & P2 & P3 & P4 \\
\hline B1 & $30,33 \mathrm{f}$ & $46,33 \mathrm{cdef}$ & $36,33 \mathrm{ef}$ & $35 \mathrm{ef}$ & $44,33 \mathrm{def}$ \\
B2 & $43,33 \mathrm{def}$ & $44,33 \mathrm{def}$ & $44,33 \mathrm{def}$ & $45,33 \mathrm{cdef}$ & $48 \mathrm{cde}$ \\
B3 & $47,67 \mathrm{cdef}$ & $50,67 \mathrm{bcde}$ & $55,33 \mathrm{bcd}$ & $58 \mathrm{abcd}$ & $57,67 \mathrm{bcd}$ & $73,67 \mathrm{a}$ \\
\hline
\end{tabular}

BNJ 5\%

17,41

Keterangan : Angka yang diikuti oleh huruf yang sama berbeda tidak nyata pada uji BNJ 5\%

Tabel 5. Uji BNJ 5\% pengaruh berat bibit terhadap jumlah tunas

\begin{tabular}{ccc}
\hline \multirow{2}{*}{ Berat Bibit } & \multicolumn{2}{c}{ Jumlah Tunas (batang) } \\
\cline { 2 - 3 } & 60 HST & $21,73 \mathrm{a}$ \\
B4 & $4,26 \mathrm{a}$ & $19,33 \mathrm{a}$ \\
B3 & $3,53 \mathrm{~b}$ & $16,13 \mathrm{~b}$ \\
B2 & $3,13 \mathrm{bc}$ & $14,66 \mathrm{~b}$ \\
\hline B1 & $2,86 \mathrm{c}$ & 3,16 \\
\hline
\end{tabular}

Keterangan : : Angka yang diikuti oleh huruf yang sama berbeda tidak nyata pada uji BNJ 5\% 
Tabel 6. Uji BNJ $5 \%$ pengaruh dosis pupuk NPK terhadap jumlah tunas

\begin{tabular}{ccc}
\hline Dosis NPK & \multicolumn{1}{c}{ Jumlah Tunas (batang) } \\
\cline { 2 - 3 } & 60 HST & 180 HST \\
P4 & $4 \mathrm{a}$ & $25,58 \mathrm{a}$ \\
P3 & $3,5 \mathrm{a}$ & $21,58 \mathrm{~b}$ \\
P2 & $3,66 \mathrm{a}$ & $17,91 \mathrm{bc}$ \\
P1 & $3,5 \mathrm{a}$ & $15,91 \mathrm{c}$ \\
P0 & $2,56 \mathrm{~b}$ & $8,83 \mathrm{~d}$ \\
\hline BNJ 5\% & 0,67 & 3,76
\end{tabular}

Keterangan : : Angka yang diikuti oleh huruf yang sama berbedatidak nyata pada uji BNJ 5\%

Tabel 8. Uji BNJ $5 \%$ pengaruh berat bibit dan dosis pupuk NPK terhadap jumlah tunas 90 HST

\begin{tabular}{rcccccc}
\hline & P0 & P1 & P2 & P3 & P4 \\
\hline B1 & $5 \mathrm{de}$ & $7 \mathrm{bcde}$ & $6 \mathrm{cde}$ & $7,33 \mathrm{bcde}$ & $5,33 \mathrm{de}$ \\
B2 & $5 \mathrm{de}$ & $7,33 \mathrm{bcde}$ & $6,67 \mathrm{bcde}$ & $8,33 \mathrm{abcd}$ & $8,33 \mathrm{abcd}$ \\
B3 & $4 \mathrm{e}$ & $8,67 \mathrm{abcd}$ & $9 \mathrm{abcd}$ & $8,33 \mathrm{abcd}$ & $10,67 \mathrm{ab}$ \\
B4 & $5,33 \mathrm{de}$ & $6,67 \mathrm{bcde}$ & $11,67 \mathrm{a}$ & $9,67 \mathrm{abc}$ & $11,67 \mathrm{a}$ \\
\hline BNJ 5\% & & 4,13 & & &
\end{tabular}

Keterangan : Angka yang diikuti oleh huruf yang sama berbeda tidak nyata pada uji BNJ 5\%

Tabel 9. Uji BNJ $5 \%$ pengaruh berat bibit dan dosis pupuk NPK terhadap jumlah tunas 120 HST

\begin{tabular}{rcccccc}
\hline & P0 & P1 & P2 & P3 & P4 \\
\hline B1 & 10,67 fghi & $17 \mathrm{bcde}$ & $7,33 \mathrm{hij}$ & $16,67 \mathrm{bcde}$ & $13,33 \mathrm{cdefg}$ \\
B2 & $10,33 \mathrm{ghij}$ & $5,33 \mathrm{ij}$ & $14,33 \mathrm{bcdefg}$ & $16,33 \mathrm{bcdef}$ & $17,67 \mathrm{bcd}$ \\
B3 & $5,33 \mathrm{j}$ & $23,67 \mathrm{a}$ & $8,67 \mathrm{ghij}$ & $18,67 \mathrm{abc}$ & $20 \mathrm{ab}$ \\
& B4 & $11,67 \mathrm{efgh}$ & $12,33 \mathrm{defgh}$ & $19 \mathrm{abc}$ & $12,67 \mathrm{defgh}$ & $24,33 \mathrm{a}$ \\
\hline BNJ 5\% & & 5,77 & & &
\end{tabular}

Keterangan : : Angka yang diikuti oleh huruf yang sama berbeda tidak nyata pada uji BNJ 5\%

Tabel 10. Uji BNJ $5 \%$ pengaruh berat bibit dan dosis pupuk NPK terhadap jumlah junas 150 HST

\begin{tabular}{cccccc}
\hline & P0 & P1 & P2 & P3 & P4 \\
\hline B1 & $7 \mathrm{f}$ & $12,7 \mathrm{def}$ & $13 \mathrm{def}$ & $16,3 \mathrm{bcde}$ & $17,3 \mathrm{bcde}$ \\
B2 & $7,33 \mathrm{f}$ & $15 \mathrm{cdef}$ & $13,7 \mathrm{def}$ & $19,7 \mathrm{bcd}$ & $20 \mathrm{bcd}$ \\
B3 & $7,33 \mathrm{f}$ & $17,3 \mathrm{bcde}$ & $22,3 \mathrm{abc}$ & $21 \mathrm{bcd}$ & $24,7 \mathrm{ab}$ \\
B4 & $10,7 \mathrm{ef}$ & $14,7 \mathrm{cdef}$ & $21 \mathrm{bcd}$ & $23 \mathrm{abc}$ & $29,7 \mathrm{a}$ \\
\hline
\end{tabular}

BNJ 5\% 8,62

Keterangan : Angka yang diikuti oleh huruf yang sama berbeda tidak nyata pada uji BNJ 5\%

Tabel 11. Uji BNJ $5 \%$ pengaruh berat bibit terhadap berat basah rimpang 180 HST

\section{Berat Bibit}

B4

B3

B2

B1

\section{Berat Basah Rimpang (g)}

629.26 a

$525.19 \mathrm{ab}$

360.25 bc

$248.54 \mathrm{c}$

BNJ 5\% = 197.28

Sumber : Hasil analisis data penelitian 2018

Keterangan : Angka yang diikuti oleh huruf yang sama berbeda tidak nyata pada uji BNJ 5\% 
Tabel 12. Uji BNJ $5 \%$ pengaruh dosis pupuk NPK terhadap berat basah rimpang $180 \mathrm{HST}$

\begin{tabular}{cc}
\hline Dosis NPK & Berat Basah Rimpang (g) \\
\hline P4 & $633.3 \mathrm{a}$ \\
P3 & $501.4 \mathrm{a}$ \\
P2 & $444.70 \mathrm{ab}$ \\
P1 & $407.57 \mathrm{ab}$ \\
P0 & $217.12 \mathrm{~b}$ \\
\hline
\end{tabular}

BNJ 5\% $=234.99$

Sumber : Hasil analisis data penelitian 2018

Keterangan : Angka yang diikuti oleh huruf yang sama berbeda tidak nyata pada uji BNJ 5\%

Dari hasil uji BNJ 5\% pada Tabel 3 dan 4 diatas, terjadi interaksi antara berat bibit dan pemberiana pupuk NPK, Pada umur pengamatan 150 HST dan 180 HST. Pada Umur 150 HST B4P4 berbeda nyata dengan B1P0 sampai B3P1, sedangkan pada umur 180 HST B4P4 berbeda nyata dengan B1P0, sampai B4P1. Hasil rerata berat bibit dan pemupukan NPK terhadap tinggi tanaman pada umur 150 HST terendah adalah tanaman B1P0 yaitu 29,67 cm dan hasil rerata berat bibit dan pemupukan NPK terhadap tinggi tanaman adalah tertinggi pada B4P4 tanaman yaitu $68 \mathrm{~cm}$, sedangkan pada umur 180 HST hasil rerata berat bibit dan pemupukan NPK terhadap tinggi tanaman terendah adalah tanaman B1P0 yaitu 30,33 cm dan hasil rerata berat bibit dan pemupukan NPK terhadap tinggi tanaman adalah tertinggi pada B4P4 tanaman yaitu $73,76 \mathrm{~cm}$.

Hasil analisis keragaman pada Tabel 5 pengaruh berat bibit dan pupuk NPK memberikan pengaruh nyata terhadap variabel pengamatan jumlah tunas. Berat bibit $38 \mathrm{~g}-42 \mathrm{~g}$ dan pupuk NPK $10 \mathrm{~g} /$ tanaman merupakan berat bibit dan dosis terbaik terhadap variabel pengamatan jumlah tunas. Dari hasil pengamatan diketahui bahwa perlakuan berat rimpang besar memberikan hasil paling baik selama perkecambahan. Hal ini disebabkan bobot rimpang besar memiliki cadangan makanan paling banyak. Cadangan makanan yang lebih banyak mampu mendukung tunas saat perkecambahan. Selain itu pengruh pemberian pupuk NPK juga berpengaruh nyata pada variabel pengamatan jumlah tunas. Hal ini sesuai dengan pendapat Januwati (1999) yang menyatakan bahwa kontribusi pupuk NPK menyediakan unsur hara esensil yang mempunyai fungsi dan peran tersendiri akan mempengaruhi kualitas tanaman. Peranan nitrogen adalah perangsang pertumbuahan vegetatif, yaitu menambah tinggi tanaman, merangsang tumbuhnya anakan dan membuat tanaman menjadi hijau karena merupakan bahan penyusun klorofil yang penting dalam fotosintesis.

Hasil uji BNJ 5\% pada Tabel 5 terhadap parameter jumlah tunas dengan berat bibit $8 \mathrm{~g}-12 \mathrm{~g}\left(\mathrm{~b}_{1}\right)$ berbeda tidak nyata pada umur 180 HST dengan jumlah tunas pada berat bibit $18 \mathrm{~g}-22 \mathrm{~g}\left(\mathrm{~b}_{2}\right)$. Namun berbeda nyata dengan berat berat bibit $28 \mathrm{~g}$ - $32 \mathrm{~g}$ (b3) dan $38 \mathrm{~g}-42 \mathrm{~g}\left(\mathrm{~b}_{4}\right)$. Hasil jumlah rerata berat bibit terendah pada umur 60 HST dan 180 HST $8 \mathrm{~g}-12$ $\mathrm{g}\left(\mathrm{b}_{1}\right)$ yaitu 2,86 dan 14.66 batang dan hasil rerata berat bibit tertinggi pada $38 \mathrm{~g}-42 \mathrm{~g}\left(\mathrm{~b}_{4}\right)$ tanaman yaitu 4,26 dan 21.73 batang.

Dari hasil uji BNJ 5\% terhadap jumlah tunas dengan pemberian dosis pupuk NPK $10 \mathrm{~g} /$ tanaman berbeda nyata dibandingkan dengan jumlah tunas pada pemberian dosis pupuk NPK $0 \mathrm{~g} / \operatorname{tanaman}\left(\mathrm{P}_{0}\right), 5 \mathrm{~g} / \operatorname{tanaman}\left(\mathrm{P}_{2}\right), 5 \mathrm{~g} /$ tanaman $\left(\mathrm{P}_{2}\right)$ dan 7,5 g/tanaman $\left(\mathrm{P}_{3}\right)$. Sedangkan dosis pupuk NPK 7,5 $\mathrm{g} /$ tanaman $\left(\mathrm{P}_{3}\right)$ berbeda tidak nyata dengan dosis pupuk NPK $5 \mathrm{~g} /$ tanaman $\left(\mathrm{P}_{2}\right)$ tetapi berbeda nyata dibandingkan dengan jumlah tunas dengan dosis pupuk NPK $0 \mathrm{~g} / \operatorname{tanaman}\left(\mathrm{P}_{0}\right)$ dan $2,5 \mathrm{~g} /$ tanaman $\left(\mathrm{P}_{1}\right)$. Hasil jumlah rerata jumlah tunas pemberian dosis pupuk terendah pada pemberian pupuk 0 $\mathrm{g} /$ tanaman $\left(\mathrm{P}_{0}\right)$ yaitu 8.83 batang dan hasil rerata jumlah tunas tertinggi pada pemberian dosis pupuk $10 \mathrm{~g}\left(\mathrm{P}_{4}\right)$ tanaman yaitu 25.58 batang.Dari hasil uji BNJ 5\% pada Tabel 8,9 dan 10 diatas, terjadi interaksi antara berat bibit dan pemberiana pupuk NPK, terhadap jumlah tunas Pada umur pengamatan 90 HST dan 120 HST dan 150 HST. Pemupukan pada tanaman jahe memegang peranan penting untuk meningkatkan hasil rimpang, baik pupuk organik, maupun anorganik yang akan memperbaiki tekstur, kesuburan dan drainase tanah, terutama pupuk NPK (PUSLITBANGBUN, 2007). Menurut Rosita et al.(2009), untuk menghasilkan pertumbuhan yang optimal tanaman jahe memerlukan unsur hara yang cukup banyak, khususnya NPK.

Hasil analisis keragaman pada tabel 11 dan 12 pengaruh berat bibit dan pemberian pupuk NPK terhadap berat basah rimpang umur 180 HST berpengaruh nyata terhadap variabel berat basah rimpamg dan tidak terjadi interaksi antara berat bibit dengan pemberian pupuk NPK. Berat bibit yang terbaik dalam penelitian ini adalah $28 \mathrm{~g}-32$ $\mathrm{g}\left(\mathrm{b}_{3}\right)$. Hal ini menunjukan bahwa berat bibit jahe tidak terlalu pengaruh terhadap hasil tanaman jahe. dan 7,5 g/tanaman jumlah $\left(\mathrm{P}_{3}\right)$ pupuk NPK merupakan dosis terbaik terhadap variabel berat basah rimpang. Hal ini diduga karena pada dosis 7,5 g/tanaman yang diberikan mampu menyediakan unsur hara yang seimbang bagi pertumbuhan tanaman jahe. Hal ini karena unsur hara yang dibutuhkan tanaman dalam pembentukan rimpang terpenuhi dalam keadaan seimbang salah satunya unsur hara fosfat dan kalium. Hal ini sesuai dengan pandapat Marsono dan Sigit (2001) yang mengemukakan bahwa pemupukan NPK pada tanaman jahe dalam keadaan cukup dapat berperan dalam meningkatkan kesehatan tanaman. Pupuk fosfat dan kalium dapat membantu perkembangan akar, membantu pembentukan protein dan karbohidrat dan meningkatkan daya tahan tanaman terhadap penyakit. Umumnya tanaman yang kekurangan unsur kalium, komponen ketahanannya akan tergannggu sehingga akan memudahkan pathogen untuk penetrasi.

Hasil uji BNJ $5 \%$ pada Tabel 11, terhadap berat basah rimpang dengan berat bibit $38 \mathrm{~g}-42 \mathrm{~g}\left(\mathrm{~b}_{4}\right) \mathrm{g} / \mathrm{tanaman}$, berbeda nyata dengan berat basah rimpang dengan berat bibit 
$8 \mathrm{~g}-12 \mathrm{~g}\left(\mathrm{~b}_{1}\right)$ dan $18 \mathrm{~g}-22 \mathrm{~g} /$ tanaman tapi berbeda tidak nyata dengan berat basah rimpang dengan berat bibit $28 \mathrm{~g}$ $32 \mathrm{~g}\left(\mathrm{~b}_{3}\right)$. Hasil jumlah rerata berat basah rimpang terendah 8 $\mathrm{g}-12 \mathrm{~g}\left(\mathrm{~b}_{1}\right)$ yaitu $3248.54 \mathrm{~g}$ dan hasil rerata berat basah rimpang tertinggi pada $\left.38 \mathrm{~g}-42 \mathrm{~g} \mathrm{(} \mathrm{b}_{4}\right)$ tanaman yaitu 629.26 g.

Hasil uji BNJ 5\% pada Tabel 12 terhadap berat basah rimpang dengan pemberian dosis pupuk sebanyak 10 $\mathrm{g} /$ tanaman $\left(\mathrm{P}_{4}\right)$ berbeda nyata dibandingkan dengan berat basah rimpang pada pemberian dosisi pupuk $0 \mathrm{~g} / \mathrm{tanaman}$ $\left(\mathrm{P}_{0}\right)$, namun berbeda tidak nyata dengan berat basah rimpang pada pemberian dosis 7,5 g/tanaman $\left(\mathrm{P}_{3}\right)$. Hasil jumlah rerata berat basah rimpang terendah pada pemberian dosis pupuk NPK 0 g/tanaman $\left(\mathrm{P}_{0}\right)$ yaitu $217.12 \mathrm{~g}$ dan hasil rerata berat basah rimpang tertinggi pada pemberian dosis pupuk 10 $\mathrm{g} / \operatorname{tanaman}\left(\mathrm{P}_{4}\right)$ yaitu $633.3 \mathrm{~g}$.

\section{KESIMPULAN}

Terjadi interaksi antara berat bibit dan pupuk NPK terhadap variabel pengamatan tinggi tanaman pada umur 150 HST dan 180 HST, jumlah tunas pada umur 90 HST, 120 HST, 150 HST dan berat kering rimpang pada umur 60 HST.

Berat bibit yang terbaik pada penelitian ini adalah pada perlakuan $28 \mathrm{~g}-32 \mathrm{~g}$. dosis pupuk NPK terbaik dalam penelitian ini adalah pada perlakuan 7,5 g/tanaman. Perlakuan berat bibit dan pupuk NPK berpengaruh nyata terhadap variabel pengamatan antara lain: tinggi tanaman, jumlah tunas, berat basah rimpang, berat kering rimpang, namun tidak berpengaruh nyata pada variabel pengamatan laju tumbuh relatif dan nisbah anakan.

\section{DAFTAR PUSTAKA}

Hailemichael, G. dan K. Tesfave. 2008. The effect of seed rhizome size on the growth,yield, and economic return of ginger (Zingiber officinale Rosc.). Asian $J$. PlantSci, 7 : 213- 217.

Januwati, M., 1999. Optimalisasi Usaha Tani Tanaman Jahe. Makalah Disampaikan pada Semi Orasi di Balai Penelitian Tanaman Rempah dan Obat Bogor, 23 Juni 1999. 31 hal.

Marsono dan P. Sigit, 2001. Pupuk Akar. Penebar Swadaya, Jakarta

PUSLITBANGBUN, 2007. Teknologi Unggulan Jahe Budidaya Pendukung Varietas Unggul. Puslitbangbun. Balitbang Pertanian. 17 hal.

Radjagukguk, B., 1991. Utilization and Management of Peatland in Indonesia for Agriculture and Forestry. Symposium on Tropical Peatland. Kuching.

Rosita, et al. 2009. Polapertumbuhan dan serapan hara $N, P$ dan $K$ tanaman bangle(Zingiber purpurium Roxb). Jurnal Littri. 1:32-36 